\title{
Governmental Financial Statement Note Disclosures and Analysis of Texas Public Two-Year Colleges' Reporting
}

\author{
Mary Fischer \\ The University of Texas at Tyler
}

Generally Accepted Accounting Principles (GAAP) requires state and local governments, public colleges and universities, and other governmental entities to issue basic financial statements, management's discussion and analysis, and required supplementary information (GASB 34, 1999a, 6). The notes to the financial statements are an integral part of the basic financial statements and consist of disclosures about the governmental entity. The notes provide qualitative and quantitative information to help financial statement users better understand the numbers on the face of the financial statements. This study investigates Texas two-year college 2014 financial statements to determine the extent of note disclosures and compliance with the Texas Higher Education Coordinating Board (THECB) requirements. The investigation also seeks to determine if a difference in compliance and disclosure exists between the financial statements audited by local, regional, or national accounting firms and finds that types of disclosure and auditor together with size, revenue, enrollment, tuition and state appropriate explain the number of required note disclosures, additional note disclosures and policy disclosures.

Keywords: Two-year Colleges, Financial Statement Disclosures, Compliance, Voluntary Disclosures

\section{INTRODUCTION}

Generally accepted accounting principles (GAAP) requires state and local governments, public colleges and universities, and other governmental entities to issue a management discussion and analysis, basic financial statements, and notes to the financial statement (GASB, 1999a, p. 6). The notes to the financial statements are an integral part of the basic financial statements providing qualitative and quantitative information about the government entity that does not appear on the face of the financial statement but is necessary for fair presentation (GASB, 1999a, p. 113). Currently, GAAP Codification lists 17 disclosures that are required in order for the financial statements to be fairly presented, and another 63 disclosures that may be reported when applicable (GARS, 2018).

In general, there are three types of note disclosures: disclosures that describe methods, policies, and choices that affected the numbers and data on the financial statements; disclosures that provide an explanation of the reported numbers; and disclosures that explain information that does not meet the criteria to be recognized on the face of the financial statement (GASB, 2009). 
This study provides an overview of current Governmental Accounting Standards Board (GASB) required financial statement disclosures and adds to the disclosure literature by analyzing the 50 Texas two-year college required and voluntary disclosures' utilization and practice.

\section{DISCLOSURE LITERATURE REVIEW}

The objective of financial statement note disclosures is to provide additional, relevant information useful for decision-making (Henderson, 2019). Financial statement note disclosures have become so extensive so as to become a concern about information overload in financial reporting (Ketz, 2019). Lawrence (2013) expresses concern about existing financial statement note disclosures being relevant so as to provide better decision making. Dahm, Gonzalez and Porteiro (2018) claim a reporting entity must balance a trade-off between the quality and the quantity of information included in the financial report notes disclosure. In the past decade, DeViney (2017) reports an average of three new GASB statements are issued each year for implementation including new disclosures plus permitted early adoption.

In 1985, Peat Marwick Mitchell and Co published the first in a series of college and university financial statement presentation and disclosure analyses. The series evolved away from presentation and disclosure to address only ratio analysis in higher education (Tahey et al., 2016). Meanwhile, researchers in other countries set the pace for college and university disclosure research. In New Zealand, Dixon and Coy were leaders (Dixon et al., 1991; Dixon et al., 1994; Coy et al., 1993; Coy et al., 1994). In the United Kingdom, Gray and Haslam (1990) addressed accounting changes. In Canada, Banks and Nelson (1994) looked at the disclosures of Ontario Universities. These studies tended to be longitudinal designed to measure change over time rather than to explain differences in disclosure practices.

Meanwhile, Coy joined U.S. researchers to study a new paradigm for college reporting (Coy et al., 2001). In 2002, U.S. researchers reported a comparative empirical examination of the extent of disclosures of U.S. colleges and universities (Gordon et al., 2002). In 2004, Fischer, Gordon, Greenlee and Keating, examined disclosures as they relate to private university operating measures that set the stage for a subsequent Fischer et al. 2010 study. Meanwhile, Coy and Dixon (2004) developed a public accountability index using disclosures of New Zealand universities that has not been replicated in the U.S. In 2010, Fischer with other researchers report the impact of major required changes in U.S. colleges and universities' financial reporting. Although disclosures were not the primary basis of the 2010 study, disclosures were included as they impacted institutional operations.

Although a dearth of financial statement disclosure analysis has been reported regarding corporate entities, college and university reporting studies all addressed four-year institution and did not include disclosures at lower division institutions i.e., two-year institutions. Thus, this study adds to the literature by the analysis of the Texas two-year institutions and their annual financial statement disclosure profile.

\section{Governmental Entities}

FASB and GASB reporting requirement differences stem from their reporting missions. FASB operates under a decision utility focus while GASB relies on accountability (Goldstein \& Menditto, 2005). The four major differences between the standards are: recognition, measurement, display, and disclosure. Examples of these differences include: the recognition of contributed services, the measurement of pension liabilities, the display of the balance sheet, and the required disclosures in the notes to the financial statements (Fischer \& Marsh 2012, p. 433).

Studies have been conducted on the efficiency of the required disclosures under the FASB and GASB, specifically relating to the college and university financial reporting model after major changes. The results determined that colleges and universities improved disclosure reporting as a result of financial reporting changes (Fischer et al. 2010). The amount of disclosures increased, and GASB disclosures improved on an importance-weighted disclosure index and an unweighted expanded disclosure index.

In general, GASB sets forth more stringent guidelines for governmental entities to follow. GASB Statement No. 35, Basic Financial Statements and Management's Discussion and Analysis- for Public Colleges and Universities, discusses disclosures on capital assets, long-term liabilities, collections, donor- 
restricted endowments, and segment information (GASB 1999b, p. 59). Other disclosures for public colleges and universities are provided in GASB Statement Nos. 34 and 38 as well as other statements that apply to governmental entities (GASB, 1999a; GASB, 2001).

\section{GASB'S DISCLOSURE GUIDANCE}

\section{GASB Statement No. 38}

In general, GASB incorporates disclosure guidance when issuing standards to direct specific recognition and reporting for GAAP updates and/or changes. However, Statement No. 38 Certain Financial Statement Note Disclosures (GASB, 2001) "fill[ed] the gaps where disclosure requirements were missing, clarify[ed] requirements where standards were not detailed, and discard[ed] requirements that have outlived their usefulness" (Klasny et al., 2002, 66). GASB reviewed the note disclosures required in guidance issued through 1994, excluding deposits with financial institutions, risk financing, and the reporting entity guidance. Those statement disclosures were not changed or removed because they were considered relevant and complete by GASB. Such disclosures include accounting policies, cash and cash equivalents, revenue recognition, and 27 other issues (GASB, 2001, p. 68). Disclosures amended or established by GASB 38 are: "summary of significant accounting policies, actions taken to address violations of significant finance-related legal and contractual provisions, debt and lease obligations, short-term debt, disaggregation of receivable and payable balances, and interfund balances and transfers" (GASB, 2001, p. 67). Based on the research conducted by GASB, these disclosures needed revision or exclusion because they were no longer meeting the needs of the financial statement users.

The summary of significant accounting policies disclosure revision stems from the issuance of GASB 34 that changed the focus of the basic financial statements from fund types to major funds. Disclosures must report activities in the major funds, internal service funds, and fiduciary fund types (Klasny et al., 2002, p. 66; GASB, 2001, p. 6). Such disclosures should present details about the specific government in order to distinguish between the funds. Also, governments must include in the summary of significant accounting policies, "the length of time used to define available for purposes of revenue recognition in the governmental fund financial statements" (GASB, 2001, p. 7). The prior revision to this disclosure was the elimination of the accounting policy for reporting encumbrances.

The disclosure for violations of finance-related legal or contractual provisions was affected by GASB 38 because governments must disclose the steps taken to identify and address violations of this nature (GASB, 2001, p. 9). The information must be fact-based to enable the financial statement users to understand the impact of such violations (Klasny et al., 2002, p. 67). Another disclosure amended by Statement No. 38 is related to debt and lease obligations. Principal and interest requirements must be displayed separately, together with the debt service for the past five years (Klasny et al., 2002, p. 67).

Short-term debt disclosures were addressed in GASB 38 to clarify that a schedule of changes and the purpose of borrowing are disclosed even if the entity has no outstanding short-term debt at year-end (Klasny et al., 2002, p. 67). Governments may aggregate receivable and payable balances on the statement of net position but must include a disclosure note to identify the major components of receivable and payable balances in the notes to the financial statements (GASB, 2001, p. 13).

The final disclosure affected by GASBS 38 is interfund balances. Governmental entities must report the fund that provided the transfer, a description of how the transfer was used, and any unusual transfers made by a fund. This disclosure helps clarify the owed balance at year-end, and the purpose of the transfer (Klasny et al., 2002, p. 67). Since the issuance of Statement No. 38, GASB has addressed note disclosures in other guidance to further meet the users' needs and increase understandability and comparability of the financial statements.

\section{Deposit and Investment Risk}

GASB Statement No. 40, Deposit and Investment Risk Disclosures (GASB, 2003) updated the disclosure requirements for credit risk, custodial credit risk, interest rate risk, and foreign currency risk. GASB 40 became effective for the periods beginning after June 2004. GASB 40 requires entities to 
disclose their deposit and investment policies that are related to the risks previously mentioned in addition to the separate disclosures for each risk (GASB, 2003, p. 5).

Credit risk is addressed in Statement No. 53, Accounting and Financial Reporting for Derivative Instruments, (GASB, 2008) amended GASB 40 to require any exposure to credit risk be disclosed along with the following: credit quality ratings of counterparties, the maximum possible loss that the government could incur due to credit risk, the government's policy of requiring collateral or other security to support hedging derivative instruments subject to credit risk, and the government's policy of entering into master netting arrangements. Also, the aggregate fair value of hedging derivative instruments in asset (positive) positions net of collateral posted by the counterparty and significant concentrations of net exposure to credit risk with counterparties must also be included in the disclosure note (GASB, 2008, p. 73).

Custodial credit risk is "the risk that a government will not be able to recover deposits if the depository financial institution fails or will not be able to recover collateral securities that are in the possession of an outside party" (Loyd \& Crawford, 2010, p. 1). If a governmental entity has deposits exposed to custodial credit risk, they must disclose the amount of the bank balances; a statement that the balance is uninsured; and, whether the deposits are uncollateralized, collateralized with securities held by the pledging financial institution, or collateralized with securities held by the pledging financial institution's trust department or agent but not in the depositor-government's name (GASB, 2003, p. 8).

GASBs 40 and 53 include disclosure requirements for interest rate risk. Statement No. 53 provides that when interest rate risk increases, the governmental entity must disclose the increased risk, and the terms that increase the risk (GASB, 2008, p. 73). This information is displayed by investment type and amount using one of the following methods: segmented time distribution, specific identification, weighted average maturity, duration, or simulation model. The method is selected based on its consistency with the method already in place to identify and manage interest rate risk. Highly sensitive investments require additional disclosures such as coupon multipliers, benchmark indexes, reset dates, and other information (GASB, 2003, p. 15).

Lastly, GASB 40 requires governments to disclose if any deposits or investments are exposed to foreign currency risk. Disclosures for this risk include: the U.S dollar balances of the deposits or investments presented in order of currency denomination and the types of investments that are exposed (GASB, 2003, p. 17). Disclosures for deposit and investment risks are important because deposits and investments are inherently risky that can affect the governmental entities' ability to provide services and meet obligations. Disclosing this information allows the financial statement users to evaluate the risks of the government.

\section{Pension Plan Disclosures and Other Postemployment Benefits}

Prior to GASB's issuance of Statement Nos 67 Financial Reporting for Pension Plans (GASB, 2012) and 68 Accounting and Financial Reporting for Pension (GASB, 2013), accounting for pension plans guidance was provided by GASB Statement No. 27, Accounting for Pensions by State and Local Governmental Employers (GASB, 1994). Amendments to Statement No. 27 were provided in GASB Statement No 50, Pension Disclosures (GASB, 2007). GASB issued Statement Nos. 67 and 68 on pension plan accounting to supersede Statements No's 25 and 27 effective fiscal years fiscal years 2014 and 2015, respectively. These new standards significantly expand the way governmental entities calculate, recognize, and disclose their pension plan assets and liabilities in their financial statements (Chase, 2013, p. 9).

Statement No. 27 requires governments to report the following information about their plan's description in the notes to the financial statements: name of the plan; identification of the entity that administers the plan; whether the plan is a single-employer, agent multiple-employer, or cost-sharing multiple-employer plan; descriptions of the benefits of the plan; and, whether the pension plan issues a stand-alone financial report, or is included with another entity (GASB, 1994, 20). The next part of disclosures relates to the funding policy adopted by the plan. This section of disclosures must include: "authority under which the obligations to contribute to the plan of the plan members, employer(s), and 
other contributing entities (for example, state contributions to local government plans) are established or may be amended [and] required contribution rate(s) of active plan members" (GASB, 1994, 20).

GASB Statement No. 67 effective for the fiscal year 2014 superseded GASB 27 by retaining the reporting criteria and adding the recognition of the liability associated with the pension benefits on the face of the financial statements rather than disclosure only in the notes to the financial statements. Statement 67 presents disclosures for defined benefit plans, specifically pension plans administered through trusts with certain characteristics, such as: "contributions from employers and nonemployers contributing entities to the pension plan and earnings on those contributions are irrevocable; pension plan assets are dedicated to providing pensions to plan members in accordance with the benefit terms; [or] pension plan assets are legally protected from the creditors of employers, nonemployers contributing entities, and the pension plan administrator" (GASB, 2012).

Disclosures are increased by this standard for defined benefit plans by requiring the types of benefits provided, the classes of plan members covered in the plan, and disclosure of the plan's board (Apostolou, 2013, p. 31). Additional disclosures include: "information about pension plan investments, including investment policies, a description of how fair value is determined, concentrated investments with individual organizations equaling or exceeding $5 \%$ of the pension plan's fiduciary net position, and the annual money-weighted rate of return on pension plan investments" (Apostolou, 2013, p. 31). GASB 67 also provides disclosures for single and agent employer plans which will disclose the total pension liability, the plan's fiduciary net position, beginning and ending balances of the net pension liability with the changes during the current period, and assumptions used to calculate the pension liability. Inflation, salary changes, ad hoc postemployment benefit changes, inputs to the discount rate, and mortality assumptions are required in the assumption's disclosure (Apostolou, 2013, p. 31).

Standard No. 68, effective for periods beginning after June 2014 provides guidance for governments that sponsor or contribute to state or local pension plans; therefore, it applies to the employers (GASB, 2013). Disclosures resulting from this statement vary depending on the type of employer. Single and agent employers must disclose beginning and ending balances of the pension liability, plan net position, net pension liability, and changes during the period. Also, governmental entities must disclose the amount of pension expense recognized during the period together with beginning and ending reconciliations of deferred outflows/inflows of resources (Apostolou, 2013, p. 34).

Disclosures for cost-sharing multiple-employer plans include "the total pension liability, the plan's net position, the net pension liability, the ratio of the plan's net position to total pension liability, the covered-employee payroll, and the ratio of net pension liability to covered-employee payroll for its proportionate share of the aggregate amounts" (Apostolou, 2013, p. 34). Separate disclosures are necessary for special funding situations which require the employer to disclose any information about the support provided by the nonemployer contributions, and any additional involvement (Apostolou, 2013, p. 34). The new pension guidance creates several changes to pension accounting. Governmental entities must report the net pension liability as a liability (asset) on the face of the financial statements, projected benefit payments are discounted using the effective rate of return (ERR) unless plan assets when considered insufficient to meet future needs, a uniform method for allocating the present value of benefit payments to employee's present/past service versus future service are used, and there will be changes in the way immediate and deferred pension expenses are calculated (Easterday, 2012, p. 28). All of these changes increase disclosures in order to enhance transparency and recognition of pension plan obligations.

After GASB updated pension plan reporting, a new standard was issued to address other postemployment benefits (OPEB). GASB Statement No. 75 Accounting and Reporting for Postemployment Benefits Other than Pensions (GASB, 2015a) requires governments to actuarily calculate the discontinued projected OPEB benefit costs and recognize the associated liability on the face of the financial statement (Gauthier, 2015). A required note disclosure displays specifics of the OPEB plan costs together with any plan earnings in accordance with the OPEB terms. Like pension plan assets, any OPEB plan assets are legally protected from the government's creditors. 
With the completion of accounting and reporting guidance for pension and other employee benefits, the GASB issued its second disclosure only guidance.

\section{Tax Abatement}

GASB issued Statement No. 77 Tax Abatement Disclosures (GASB, 2015b) to require governments that enter into tax abatement agreements to disclose a brief description of the tax being abated, the gross dollar about of the abated taxes and any commitments made by the government. Property tax abatement is a full or partial reduction in the normal property tax liability owed to governmental taxing authorities (Wassmer, 2014). The potential benefits of tax abatements are to enhance economic development (Harris et al., 2014). This disclosure recognition is effective for financial reporting periods beginning after December 2015 and should provide greater transparency about the nature and magnitude of tax abatements. Governments adopting the tax abatement reporting guidance early achieved little transparency beyond the program type and the total amount abated (Fischer \& Holmes, 2018). None of the colleges in this study early adopted the tax abatement reporting Statement No. 77.

\section{DISCLOSURE GUIDANCE UTILIZATION}

The 50 public two-year colleges in accordance with Texas state statues annually present an independent certified public accountant audited annual financial report to the Higher Education Coordinating Board (THECB). Texas public two-year colleges are independent 501(c)3 organizations with an independent governing board. They each have taxing authority, receive state appropriates for support, and submit their audited financial reports to THECB by January 1 of the year following the end of their fiscal year.

Based on an analysis of Texas two-year public college financial reporting (Alwin, 1990), the Texas Higher Education Coordinating Board (THECB) develops and updates annually a financial reporting instruction and requirements manual (THECB, 2018). The manual provides a comprehensive set of definitions, rules, formats and illustrations for Texas public community and junior colleges to prepare consistent and uniform GAAP financial reports. In Section 7 of the manual Notes to the Financial Statement, THECB selected 20 of the GASB required note disclosures (GARS, 2018) and added an another eight to complete a set of 27 note disclosures required to be included in the Texas two-year public colleges' financial report. The Board selected 13 policies from the GASB required accounting policies (GARS, 2018) and added another two to complete a set of 15 required significant accounting policies to be included in the two-year public colleges' financial report. Thus Section 7 of the manual prescribes 27 specific note disclosures and another 15 significant accounting policies to be included in the Texas twoyear public colleges' annual financial reports. Additional note and policy disclosures as appropriate are encouraged.

This research effort investigates the 50 Texas two-year colleges' 2014 annual financial reports to determine the extent of compliance of note and accounting policy disclosure. The investigation also seeks to determine the level to which additional notes and policies are disclosed and if the difference is explained by variable such as auditor size, or other information.

\section{DATA COLLECTION}

The 2014 audited annual financial statement for all 50 two-year Texas community or junior colleges was retrieved from THECB www files (THECB, 2014). The financial statement for each college was analyzed and tabulated for GAAP reporting and disclosure identifying whether the disclosure was a note or a significant accounting policy. The disclosure of the required note and policy disclosures were analyzed. The additional note and policy disclosures were also tabulated. Demographic information collected for each college included enrollment, audit opinion, receipt of 2014 GFOA Certificate of Excellence and the audit firm that performed the audit together with operating financial support was collected. The audit firms were classified as local, regional, large regional or large national, i.e., Big Four. 
The enrollment at the 50 Texas two-year public colleges ranged from a low of 833 (Frank Phillips College) to a high of 47,937 at Dallas County College (THECB, 2015). The overall average enrollment was 9,344 full time equivalent students.

A majority of the colleges were audited by local CPA firms (72 percent). All 50 of the Texas twoyear colleges received a fairly presented auditor opinion with the exception of Alvin Community College that received a disclaimer in the audit opinion because the College included a discrete affiliated organization presentation of the unaudited Alvin Community College Foundation to satisfy GASB No. 39 Determining Whether Certain Organizations are Component Units (GASB, 2002) in their financial statements.

An analysis of THECB required note and policy disclosures finds that all of the colleges included 100 percent of four of the required notes and two of the required policies. Overall note compliance is 69.18 percent with 57 notes presented that were not required by THECB. Overall policy compliance is 82.2 with 70 significant policies reported that were not required. It is interesting to note that GASB No. 38 (2001) requires disaggregated disclosure of both receivables and payables but THECB only requires the disaggregated receivable disclosed. A disaggregated payable was the more frequent voluntary presentation (94 percent).

Only one college was 100 percent compliant with the Texas Coordinating Board reporting criteria for both notes and policy disclosure (South Plains College). The other 49 colleges' compliance ranged from 48.14 percent to 100 percent for note disclosure and from 53.3 percent to 100 percent for policy disclosures. The average college compliance for note disclosure is 69.2 percent where the average college compliance for policy disclosure is much higher at 82.2 percent. The average number of additional notes disclosed is 6 but the average additional policy disclosures are lower at only 4 .

\section{ANALYSES DESIGN}

To determine the extent of note and accounting policy disclosure and whether the difference is explained by auditor, size or other variables, selected data was collected from the Texas two-year colleges' data in THECB files (THECB, 2014; THECB, 2015). The selected variables together with their definitions are the following. 
TABLE 1

VARIABLE DEFINITION AND MEASURE

\begin{tabular}{|l|l|}
\multicolumn{1}{c}{ Variable } & \multicolumn{1}{c|}{ Definition or Measurement } \\
\hline Required note disclosures (REQNOTE) & Number of THECB required note disclosures \\
\hline $\begin{array}{l}\text { Additional Nonrequired Notes } \\
\text { (ADDNOTE) }\end{array}$ & $\begin{array}{l}\text { Number of notes disclosed not required by } \\
\text { THECB }\end{array}$ \\
\hline Required Policy Disclosures (REQPOL) & Number of THECB required policy disclosures \\
\hline $\begin{array}{l}\text { Additional Policy Disclosures } \\
\text { (ADDPOL) }\end{array}$ & $\begin{array}{l}\text { Number of policies disclosed not required by } \\
\text { THECB }\end{array}$ \\
\hline GFOA Certificate of Excellence (GFOA) & $\begin{array}{l}1=\text { received certificate; } 0=\text { no certificate } \\
\text { received }\end{array}$ \\
\hline Full Time Equivalent Enrollment (FTE) & $\begin{array}{l}\text { Number of full-time equivalent students } \\
\text { enrolled (proxy for size) }\end{array}$ \\
\hline & $\begin{array}{l}1=\text { local firm, } 2=\text { regional firm, } 3=\text { large } \\
\text { regional firm, } 4=\text { national firm, } 5=\text { large } \\
\text { national firm (Big 4) (proxy for reporting } \\
\text { expertise) }\end{array}$ \\
\hline Audit Firm (AUDITOR) & Tuition revenue (proxy for size) \\
\hline Tuition (TUITION) & $\begin{array}{l}\text { Appropriation revenue based on formula } \\
\text { funding (relates to FTE size) }\end{array}$ \\
\hline State Appropriation (STAPPOR) & Local tax revenues (proxy for wealth) \\
\hline Ad Valorem Tax (ADVOR) & Operating gain or loss (performance measure) \\
\hline Net Position Change (NETCHG)
\end{tabular}

Four questions were developed to analyze the extent to which variables in the study explain the Texas two-year colleges' note and accounting policy disclosure.

\section{Research Question 1}

Does the number of nonrequired note disclosure, all types of policy disclosures, size, expertise, wealth, GFOA recognition or performance measure explain the number of required notes disclosed? The question results in the following hypothesis.

$\boldsymbol{H}_{1:} \quad$ REQNOTE will be positively associated with AUDITOR and PERFORMANCE

The following linear regression model, Model 1, is used to test the hypothesis:

$$
\begin{gathered}
\text { REQNOTE }=\beta_{1} \text { ADDNOTE }+\beta_{2} \text { REQPOL }+\beta_{3} \text { ADDPOL }+\beta_{4} \text { GFOA }+\beta_{5} \text { FTE }+\beta_{6} \text { AUDITOR }+ \\
\beta_{7} \text { TUITION }+\beta_{8} \text { STAPPOR }+\beta_{9} \text { ADVOR }+\beta_{10} \text { NETCHG }
\end{gathered}
$$

\section{Research Question 2}

Does the number of all types of note disclosures, nonrequired policy disclosures, size, expertise, wealth, GFOA recognition or performance measure explain the number of required policy disclosures? The question results in the following hypothesis.

$H_{2:}$ REQPOL will be positively associated with AUDITOR and PERFORMANCE 
The following linear regression model, Model 2, is used to test the hypothesis.

$$
\begin{gathered}
\mathrm{REQPOL}=\beta_{1} \mathrm{REQNOTE}+\beta_{2} \text { ADDNOTE }+\beta_{3} \text { ADDPOL }+\beta_{4} \text { GFOA }+\beta_{5} \text { FTE }+\beta_{6} \text { AUDITOR }+ \\
\beta_{7} \text { TUITION }+\beta_{8} \text { STAPPOR }+\beta_{9} \text { ADVOR }+\beta_{10} \text { NETCHG }
\end{gathered}
$$

\section{Research Question 3}

Does the number of required note disclosures, all types of policy disclosures, size, expertise, wealth, GFOA recognition or performance measure explain the number of nonrequired note disclosures? The question results in the following hypothesis.

$\boldsymbol{H}_{3:}$ ADDNOTE will be positively associated with AUDITOR and PERFORMANCE

To test the hypothesis, the following linear regression model, Model 3, is used.

$$
\begin{gathered}
\text { ADDNOTE }=\beta_{1} \text { REQNOTE }+\beta_{2} \text { REQPOL }+\beta_{3} \text { ADDPOL }+\beta_{4} \text { GFOA }+\beta_{5} \text { FTE }+\beta_{6} \text { AUDITOR }+ \\
\beta_{7} \text { TUITION }+\beta_{8} \text { STAPPOR }+\beta_{9} \text { ADVOR }+\beta_{10} \text { NETCHG }
\end{gathered}
$$

\section{Research Question 4}

Does the number of all types of note disclosures, required policy disclosures, size, expertise, wealth, GFOA recognition or performance measure explain the number of additional policy disclosures? The question results in the following hypothesis.

$\boldsymbol{H}_{4:}$ ADDPOL will be positively associated with AUDITOR and PERFORMANCE

The following linear regression model, Model 4, is used to test the hypothesis.

$$
\begin{gathered}
\mathrm{ADDPOL}=\beta_{1} \mathrm{REQNOTE}+\beta_{2} \text { ADDNOTE }+\beta_{3} \mathrm{REQPOL}+\beta_{4} \text { GFOA }+\beta_{5} \mathrm{FTE}+\beta_{6} \text { AUDITOR }+ \\
\beta_{7} \text { TUITION }+\beta_{8} \text { STAPPOR }+\beta_{9} \text { ADVOR }+\beta_{10} \text { NETCHG }
\end{gathered}
$$

\section{RESULTS}

Information pertaining to the 11 study variables was collected for each of the 50 Texas two-year colleges. Table 2 provides the descriptive statistics for all variables in the analysis and illustrates that some of the colleges complied 100\% with THECB note and accounting policy disclosure while some did not. Overall the colleges disclosed additional nonrequired notes and policies but not to an extensive number. The data also displays the colleges range from very small with low tuition, appropriations and tax revenue to large institutions with thousands of FTE and revenue. While the operating gain or loss displayed as net position change ranges from a negative $\$ 6,100$ to a high of $\$ 45,754$. 
TABLE 2

DESCRIPTIVE STATISTICS

\begin{tabular}{|c|c|c|c|c|}
\hline & Minimum & Maximum & Mean & $\begin{array}{r}\text { Std. } \\
\text { Deviation } \\
\end{array}$ \\
\hline $\begin{array}{l}\text { Required Note } \\
\text { Disclosures }\end{array}$ & 48.14 & 100.00 & 69.2046 & 12.91809 \\
\hline $\begin{array}{l}\text { Additional } \\
\text { Nonrequired Notes }\end{array}$ & 2 & 14 & 5.98 & 2.478 \\
\hline $\begin{array}{l}\text { Required Policy } \\
\text { Disclosures }\end{array}$ & 53.33 & 100.00 & 85.3734 & 11.11456 \\
\hline $\begin{array}{l}\text { Additional Policy } \\
\text { disclosures }\end{array}$ & 0 & 15 & 3.74 & 3.319 \\
\hline GFOA Cert & 0 & 1 & .28 & .454 \\
\hline FTE & 833 & 47,937 & $9,344.34$ & $11,667.247$ \\
\hline Audit Firm & 1 & 5 & 1.64 & 1.225 \\
\hline Tuition & $\$ 1,010$ & $\$ 70,689$ & $\$ 16,874.34$ & $\$ 18,894.439$ \\
\hline State Appropriation & $\$ 2,727$ & $\$ 85,709$ & $\$ 19,829.78$ & $\$ 21,183.375$ \\
\hline Ad Valorem Tax & $\$ 257$ & $\$ 209,828$ & $\$ 32,890.42$ & $\$ 50,848.184$ \\
\hline Net Position change & $\$-6,100$ & $\$ 45,754$ & $\$ 5,368.20$ & $\$ 10,486.534$ \\
\hline
\end{tabular}

TABLE 3

CORRELATION AMONG THE VARIABLES

\begin{tabular}{|c|c|c|c|c|c|c|c|c|c|c|c|c|c|c|c|c|c|c|c|c|}
\hline & Correlation Matrix & & & & & & & & & & & & & & & & & & & \\
\hline & Pearson & & & & & & & & & & & & & & & & & & & \\
\hline & Variable & 1 & & 2 & & 3 & 4 & & 5 & & 6 & & 7 & & 8 & & 9 & & 10 & \\
\hline 1 & Required Notes disclosed & & & & & & & & & & & & & & & & & & & \\
\hline 2 & Additional Nonrequired Notes Disclosed & -0.324 & $*$ & & & & & & & & & & & & & & & & & \\
\hline 3 & Required Policies Disclosed & 0.246 & & -0.078 & & & & & & & & & & & & & & & & \\
\hline 4 & Additional Nonrequired Policies Disclosed & -0.239 & & 0.513 & $* *$ & -0.027 & & & & & & & & & & & & & & \\
\hline 5 & GFOA Certificate of Excellance & -0.124 & & 0.459 & $* *$ & -0.890 & 0.280 & * & & & & & & & & & & & & \\
\hline 6 & Full Time Equivalent Enrollment & -0.028 & & 0.163 & & -0.023 & 0.345 & * & 0.549 & $* *$ & & & & & & & & & & \\
\hline 7 & Audit Firm & -0.191 & & 0.206 & & -0.018 & 0.338 & $*$ & 0.369 & $* *$ & 0.597 & $* *$ & & & & & & & & \\
\hline 8 & Tuition Revenu & 0.073 & & 0.083 & & -0.019 & 0.211 & & 0.461 & $* *$ & 0.923 & $* *$ & 0.605 & $* *$ & & & & & & \\
\hline 9 & State Appropriation Revenue & -0.076 & & 0.243 & & -0.109 & 0.341 & $*$ & 0.496 & $* *$ & 0.846 & $* *$ & 0.727 & $* *$ & 0.855 & $* *$ & & & & \\
\hline 10 & Ad Valorem Tax Revenue & -0.042 & & 0.206 & & 0.017 & 0.316 & $*$ & 0.567 & $* *$ & 0.947 & $* *$ & 0.604 & $* *$ & 0.847 & $* *$ & 0.777 & $* *$ & & \\
\hline 11 & Net Position Change & -0.031 & & 0.112 & & 0.233 & 0.270 & & 0.360 & $*$ & 0.599 & $* *$ & 0.269 & & 0.471 & $* *$ & 0.323 & * & 0.624 & ** \\
\hline & $*=.05$ (2-tailed $)$ & & & & & & & & & & & & & & & & & & & \\
\hline & $* *=.01(2$-tailed $)$ & & & & & & & & & & & & & & & & & & & \\
\hline
\end{tabular}


Four variables, FTE, TUITION, STAPPOR and ADVOR have correlations that are above .70 suggesting they could produce a multicollinearity problem. A multiple regression was performed with each independent variable regressed against the other independent variables to determine the tolerance. Hair et al. (2010) indicates a tolerance level of .10 corresponds to a Variation Inflation Factor (VIF) value of 10 but suggests a cutoff of 5 indicating a risk of multicollinearity (Hair et al., 2010, p. 204). A multiple regression was performed for each of the independent variables regressed against the other independent variables to determine the tolerance. The analysis found FTE, TUITION and ADVOR with VIF greater than 5. Based this analysis one size variable TUITION was retained in the analysis. The regression analyses with the revised variables did not have a VIF value higher than 2.2 for any variable in the model with the average VIF of 1.1 .

With the adjusted independent variables, Table 4 reflects the regression analysis of the four Models.

TABLE 4

REGRESSION ANALYSIS

\begin{tabular}{|c|c|c|c|c|c|c|c|c|}
\hline & Model 1 & & Model 2 & & Model 3 & & Model 4 & \\
\hline $\begin{array}{l}\text { Dependent } \\
\text { variable }\end{array}$ & $\begin{array}{c}\text { Required } \\
\text { Notes } \\
\text { Disclosed } \\
\end{array}$ & & $\begin{array}{c}\text { Required } \\
\text { Policies } \\
\text { Disclosed } \\
\end{array}$ & & $\begin{array}{c}\text { Additional } \\
\text { Nonrequired } \\
\text { Notes } \\
\text { Disclosed } \\
\end{array}$ & & $\begin{array}{c}\text { Additional } \\
\text { Nonrequired } \\
\text { Policies } \\
\text { Disclosed } \\
\end{array}$ & \\
\hline Observations & $\begin{array}{c}50 \\
\text { t value }\end{array}$ & & $\begin{array}{c}50 \\
\text { t value }\end{array}$ & & $\begin{array}{c}50 \\
\text { t value }\end{array}$ & & $\begin{array}{c}50 \\
\text { t value }\end{array}$ & \\
\hline $\begin{array}{l}\text { Constant } \\
\text { Required Notes }\end{array}$ & 3.52 & $* * *$ & 0.573 & $* * *$ & 2.361 & $* *$ & 0.103 & \\
\hline $\begin{array}{l}\text { Disclosed } \\
\text { Additional } \\
\text { Nonrequired Notes }\end{array}$ & & & 1.854 & $*$ & -1.385 & & -0.279 & \\
\hline $\begin{array}{l}\text { Disclosed } \\
\text { Required Policies }\end{array}$ & -1.385 & & -0.249 & & & & 3.197 & $* * *$ \\
\hline $\begin{array}{l}\text { Disclosed } \\
\text { Additional } \\
\text { Nonrequired }\end{array}$ & 1.854 & $*$ & & & 0.305 & & -0.249 & \\
\hline Policies Disclosed & -0.279 & & 0.305 & & 3.197 & $* * *$ & & \\
\hline GFOA Certificate & 0.158 & & -0.795 & & 3.118 & $* * *$ & -0.583 & \\
\hline Auditor & -1.696 & $*$ & 0.668 & & -0.13 & & 1.325 & \\
\hline $\begin{array}{l}\text { Tuition } \\
\text { Net Position }\end{array}$ & 1.767 & $*$ & -1.052 & & -0.732 & & -0.061 & \\
\hline Change & -0.865 & & 2.223 & $*$ & -0.719 & & 1.346 & \\
\hline Adjusted $\mathrm{R}^{2}$ & 0.111 & & 0.03 & & 0.343 & & 0.246 & \\
\hline F value & 1.875 & & 1.216 & & 4.66 & & 3.285 & \\
\hline Significance & 0.098 & $*$ & 0.316 & & 0.001 & $* * *$ & 0.007 & $* * *$ \\
\hline
\end{tabular}

Legend:

$*=.10$

$* *=.05$

$* * *=.01$ 
Given the information in Table $4, \mathrm{H}_{1}, \mathrm{H}_{3}$, and $\mathrm{H}_{4}$ are not rejected. The $\mathrm{H}_{2}$ model of nonrequired policy disclosures and demographic variables did not significantly explain the required disclosures and is rejected. The variables in the $\mathrm{H}_{1}, \mathrm{H}_{2}$, and $\mathrm{H}_{3}$ models explain the required note and policy disclosures that support the other three hypotheses (research questions). In fact, as the size/expertise and the performance measure increase, the reporting of required notes decreases. This relationship does not exist with policy disclosures, but they are not sufficient to significantly explain the note and accounting disclosures.

The additional note and policy disclosures are quite different. The dependent variables do explain the reporting of additional notes and policies. Although some negative relationships do exist.

A financial statement user would be advised to review the variables included in this study to draw a conclusion of the decision usefulness of the reported annual two-year a financial statement under consideration.

\section{CONCLUSION}

Governmental entities disclose information in the notes to the financial statements in order for users to better understand the financial statement numbers. Disclosures also contain information that is important to the entity operations that does not appear on the face of the financial statements. GASB required disclosures are established with the desire to increase financial statement transparency, comparability, and understandability for the financial statement users.

Although this study only analyzes public two-year colleges, these finding may or may not be relevant to four-year colleges and universities. Additional research should be undertaken to ascertain whether comparable findings exist in subsequent annual financial reports and with four-year college and university financial reporting.

\section{REFERENCES}

Alwin, L. F. (1990). Study of Junior College Financial Administration. Austin, TX: Office of State Auditor.

Apostolou, B. W. (2013). Bridging the Government Pension Reporting Gap. CPA Journal, 83(8), 31-34.

Banks, W., \& Nelson, M. (1994). Financial disclosures by Ontario universities: 1988-1993. Journal of International Auditing and Taxation, 3(2), 287-305.

Chase, B. W. (2013). The New Pension Reporting Standard. CPA Journal, 83(5), 9-10.

Coy, D., Dixon, K., \& Tower, G. (1993). Quantifying the quality of tertiary education annual reports. Accounting and Finance, 33, 121-129.

Coy, D., Dixon, K., \& Tower, G. (1994). Public sector reform in New Zealand: The progress of tertiary education annual reports 1990-1992. Financial Accountability and Management, 10(3), 253-261.

Coy, D., \& Dixon, K. (2004). The public accountability index: Crafting a parametric disclosure index for annual reports, British Accounting Review, 36(1), 79-106.

Coy, D., Fischer, M., \& Gordon, T. (2001). Public accountability: A new paradigm for college and university annual reports. Critical Perspectives on Accounting, 12(1), 1-31.

Dahm, M., Gonzalez, P., \& Porteiro, N. (2018). The enforcement of mandatory disclosure rules. Journal of Public Economics, (November) 167, 21-32.

DeViney, S. (2017). Best practices in implementing new GASB statements. Journal of Government Financial Management, (Summer) 66(2), 12-17.

Dixon, K., Coy, D., \& Tower, G. (1991). External reporting by New Zealand universities.985-1989: Improving accountability. Financial Accountability and Management, 7, 159-178.

Dixon, K., Coy, D., \& Tower, G. (1994). Tertiary education institution institutions' annual report. New Zealand Ministry of Education Study, Wellington, NZ.

Easterday, K. V. (2012). Defined Benefit Pension Plans. CPA Journal, 82(9), 28. 
Fischer, M., Gordon, T., Greenlee, J., \& Keating, E. K. (2004). Measuring operations: An analysis of US private colleges and universities' financial statements. Financial Accountability and Management, 20(2),129-151.

Fischer, M., Gordon, T. P., \& Kraut, M. A. (2010). Meeting user information needs: The impact of major changes in FASB and GASB standards on financial reporting by colleges and universities. Journal of Accountancy \& Public Policy, 29(4), 374-399.

Fischer, M., \& Holmes, A. F. (2018). Tax abatement disclosures: An exploratory study of professional's perceptions and early disclosures of GASB Statement No. 77. Journal of Applied Business and Economics, 20(8), 60-71.

Fischer, M., \& Marsh, T. (2012). Two accounting standard setters: Divergence continues for nonprofit organizations. Journal of Public Budgeting, Accounting \& Financial Management, 24(3), 429465.

Gauthier, S. J. (2015). GASB closes the loop on postemployment benefits. Government Finance Review, August, 3(4), 59-60.

Goldstein, L. L., \& Menditto S. (2005). GASB AND FASB... can you tell the two apart? Business Officer-NACUBO, 38(7), 21-27.

Gordon, T., Fischer, M., Malone, D., \& Tower, G. (2002). A comparative empirical examination of extent of disclosure by private and public colleges and universities in the United States. Journal of Accounting and Public Policy, 21(3), 235-275.

Governmental Accounting Research System (GARS). (2018). Codification. Retrieved November 5, 2018, from www.aaahq.org

Governmental Accounting Standards Board (GASB). (1994). Statement No. 27 - Accounting for Pensions by State and Local Governmental Employers. Norwalk, CT: GASB.

Governmental Accounting Standards Board (GASB). (1999a). Statement No. 34 - Basic Financial Statements - and Management's Discussion and Analysis - for State and Local Governments. Norwalk, CT: GASB.

Governmental Accounting Standards Board (GASB). (1999b). Statement No. 35 - Basic Financial Statements and Management's Discussion and Analysis-for Public Colleges and Universities. Norwalk, CT: GASB

Governmental Accounting Standards Board (GASB). (2001). Statement No. 38 - Certain Financial Statement Disclosures. Norwalk, CT: GASB.

Governmental Accounting Standards Board (GASB). (2002). Statement No. 39 - Determining Whether Certain Organizations are Component Units - an amendment of GASB Statement No. 14. Norwalk, CT: GASB.

Governmental Accounting Standards Board (GASB). (2003). Statement No. 40 -Deposit and Investment Risk Disclosures. Norwalk, CT: GASB.

Governmental Accounting Standards Board (GASB). (2007). Statement No. 50 - Pension Plan Disclosures. Norwalk, CT: GASB.

Governmental Accounting Standards Board (GASB). (2008). Statement No. 53 -Accounting and Financial Reporting for Derivative Instruments. Norwalk, CT: GASB.

Governmental Accounting Standards Board (GASB). (2009). User's Perspective - Touring the Financial Statements Part IV: Note Disclosures. Norwalk, CT: GASB.

Governmental Accounting Standards Board (GASB). (2012). Statement No. 67 - Financial Reporting for Pension Plans. Norwalk, CT: GASB.

Governmental Accounting Standards Board (GASB). (2013). Statement No. 68 - Accounting and Financial Reporting for Pensions. Norwalk, CT: GASB.

Governmental Accounting Standards Board (GASB). (2015a). Statement No. 75 - Accounting and Financial Reporting for Postemployment Benefits Other Than Pensions. Norwalk, CT: GASB.

Governmental Accounting Standards Board (GASB). (2015b). Statement No. 77 - Tax Abatement Disclosures. Norwalk, CT: GASB. 
Gray, E., \& Haslam, J. (1990). External reporting by UK universities: An exploratory study of accounting change. Financial Accountability and Management, 6, 51-72.

Hair, J. F. Jr., Black, W. C., Babin, B. J. M., \& Anderson, R. E. (2010). Multivariate Data Analysis. $7^{\text {th }}$ Edition. Upper Saddle Ridge, NJ: Prentice Hall Publishers.

Harris, J., McKenzie, K. S. M., \& Rentfro, R. (2014). Tax abatement reporting: Perspectives of users and preparers. Journal of Public Budgeting, Accounting \& Financial Management, 26(3), 429-457.

Henderson, E. (2019). Users' perceptions of usefulness and relevance of financial statement note disclosures and information overload. International Journal of Business, Accounting, \& Finance, (Spring), 13(1), 41-56.

Ketz, J. E. (2019) Confessions of an accounting critic. The CPA Journal, (March), 13-12.

Klasny, E. M., Reese, R. E., \& Morris, T. W. (2002). Note Disclosures for Governments. CPA Journal, $72(4), 66-68$.

Lawrence, A. (2013). Individual investors and financial disclosures. Journal of Accounting and Economics, 56, 130-147.

Loyd, D., \& Crawford, M. A. (2010). Questions and Answers on Specific Issues about Deposits with Financial Institutions. Governmental GAAP Update Service, 10(1), 1-7.

Peat Marwick Mitchell \& Co. (1985). Principles and presentation for higher education: A review of annual reports. New York, NY: Peat Marwick Mitchell \& Co.

Tahey, P., Salluzzo, R., Prager, F., Mezzina, L., \& Cowen, C. (2016). Update to the $7^{\text {th }}$ edition of strategic financial analysis for higher education. USA: KPMG, Prager, Sealy, \& Co., LLC, and Attain.

Texas Higher Education Coordinating Board (THECB). (2014). Annual Financial Reports Austin, TX: THECB. Retrieved from www.thecb.state.tx.us

Texas Higher Education Coordinating Board (THECB). (2015). Fall Enrollment: 2008-2014 for Texas Higher Educations Entities Austin, TX: THECB. Retrieved from reports.thecb.state.tx.us

Texas Higher Education Coordinating Board (THECB). (2018). Budget Requirements and Annual Financial Reporting Requirements for Texas Public Community Colleges. Austin, TX: THECB. Retrieved from www.thecb.state.tx.us/

Wassmer, R. W. (2014). Property tax abatement as tax expenditures? Public Finance and Management, 14(2), 194-220. 